\title{
Short communication: Evaluation of vaginal discharge following treatment with a progesterone insert
}

\author{
C. Fischer-Tenhagen, X. von Krueger, and W. Heuwieser \\ Clinic for Animal Reproduction, Freie Universität Berlin, 14163 Berlin, Germany
}

\begin{abstract}
Yellowish discharge after application of intravaginal progesterone releasing inserts is frequently observed in cows. The objective of this study was to compare the bacteriological contamination of the vagina and uterus before and after a treatment with a progesterone insert in heifers. Forty-two Holstein heifers received a progesterone releasing insert [Eazi-Breed controlled internal drug release (CIDR) insert; Pfizer Animal Health, Berlin, Germany] for $7 \mathrm{~d}$. The protruding tail had been removed from half of the inserts (no tail group: $\mathrm{n}=21$; tail group: $\mathrm{n}=21$ ). Nine heifers from the tail group lost the insert within the 7-d treatment interval and were excluded. Heifers identified in estrus were artificially inseminated on d 9 or 10. Vaginal discharge was scored on a 4-point scale [vaginal discharge score (VDS) 0 to 3] and vaginal swabs were taken for bacteriological examination on $\mathrm{d} 0$ and 7 and the day of artificial insemination (AI). Furthermore, cytological and bacteriological samples were obtained from the uterus on $\mathrm{d} 7$ and the day of AI. On d 0, coliforms and Streptococcus spp. were found in vaginal swabs of 21 heifers (64\%). On d 7 , all heifers showed purulent vaginal discharge (VDS 2 to 3$)$. The VDS was higher in the tail group compared with the no tail group. Arcanobacterium pyogenes, coliforms, and Streptococcus spp. were isolated from the vaginal swabs in 32 of $33(96 \%)$ heifers on d 7 . On the day of AI, VDS had improved to 0 or 1 in $96 \%$ of the heifers. However, A. pyogenes, coliforms, and Streptococcus spp. were still isolated in 17 of $33(53 \%)$ heifers from the vagina and in 32 of $33(96 \%)$ heifers from the endometrium. Endometrial cytology revealed polymorphonuclear neutrophils (PMN) in 11 heifers (6 to $32 \% \mathrm{PMN}$ ). Five samples exceeded the threshold of $5 \% \mathrm{PMN}$, and 2 samples exceeded the $10 \% \mathrm{PMN}$ threshold, indicative of subclinical endometritis. In conclusion, pyogenic bacteria were found in the vagina
\end{abstract}

\footnotetext{
Received December 5, 2011.

Accepted April 7, 2012.

${ }^{1}$ Corresponding author: w.heuwieser@fu-berlin.de
}

and uterus on $\mathrm{d} 7$ and the day of AI after intravaginal progesterone treatment. The severity of the discharge was affected by the protruding tail of the insert.

Key words: progesterone insert, vaginal discharge, inflammation

\section{Short Communication}

The efficacy of progesterone (P4) inserts has been intensively researched in dairy and beef heifers and cows (Lamb, 2001; Chebel et al., 2006; Stevenson et al., 2006). It has been demonstrated that these devices are efficacious to synchronize estrus in dairy and beef heifers (Lucy et al., 2001; Rivera et al., 2005) and to increase reproductive performance in dairy cows (Chebel et al., 2006; Stevenson et al., 2008). Vaginal discharge (VD) in treated cows has been mentioned by several authors. Walsh et al. (2007) described a severe VD in $57 \%$ of dairy cows, treated for $7 \mathrm{~d}$ with a progesterone insert, whereas Chenault et al. (2003) diagnosed a cloudy $(38 \%)$ or yellow $(27 \%)$ discharge after $7 \mathrm{~d}$ of controlled internal drug release insert (CIDR) treatment in $67 \%$ of 863 dairy cows. Bacteriological examinations of vaginal swabs revealed ubiquitary organisms (Bulman et al., 1978) or Arcanobacterium pyogenes, coliforms, and Streptococcus spp. (Walsh, 2008). All studies evaluated the discharge and the status of the vaginal mucosa only at the day of removal of the insert, but not on the day of the following insemination. Mucopurulent or purulent VD is indicative of uterine diseases and associated with decreased fertility (LeBlanc et al., 2002; Dubuc et al., 2010). There is a dearth of information whether the insert-mediated VD is associated with endometritis and a negative effect on fertility. Therefore, the objective of this study was to compare the bacteriological contamination of the vagina and uterus before and after a treatment with a P4 insert. Specifically, we set out (1) to examine relevant pathogens of the vagina and uterus after 7-d treatment with a P4 insert on the days of removal and AI, (2) to study inflammation in the uterus after 7 -d treatment with a $\mathrm{P} 4$ insert on the day of $\mathrm{AI}$, and (3) to determine the effect of the protruding tail on VD. 
The study was conducted on a commercial dairy farm in Brandenburg, Germany, milking 430 cows. The herd average milk yield was $9,475 \mathrm{~kg}$ ( $4.0 \%$ fat and $3.5 \%$ protein). Heifers were housed on a separate site close to the main dairy farm. They were returned to the dairy farm at the age of 9 mo and reintroduced to the production herd 6 to 8 wk before calving. The pregnancy rate at first AI was $62.5 \%$ in 2008 . Heifers were housed in a freestall barn on deep-bedded straw and were fed a TMR with corn $(66 \%)$ and grass $(34 \%)$ silage. Forty-two heifers were enrolled between June and November 2009. They were (mean \pm SD) $13.2 \pm$ 1.3 mo old, had not been previously inseminated, and did not show any signs of endometritis according to the results of transrectal palpation and vaginoscopy.

On the day of enrollment (d 0$)$, heifers $(n=42)$ were treated with a $\mathrm{P} 4$ insert (Eazi-Breed CIDR, containing $1.38 \mathrm{~g}$ of P4; Pfizer Animal Health, Berlin, Germany). Heifers were randomly assigned to 1 of 2 treatments with a random treatment allocation plan generated before the initiation of the experiment using a random number generator (Excel 2003; Microsoft Corp., Munich, Germany). The tail attached to the P4 insert was removed in group 1 (no tail, $\mathrm{n}=21$ ) but left intact in group 2 (tail, $\mathrm{n}=21$ ). Nine of 21 $(42 \%)$ heifers in the tail group lost the P4 insert before d 7. On d 7, P4 inserts were removed and $0.5 \mathrm{mg}$ of cloprostenol (2 $\mathrm{mL}$ of PGF Veyx forte; Veyx Pharma GmbH, Schwarzenborn, Germany) administered i.m. Heifers seen in estrus were artificially inseminated after $2(28 / 33,85 \%)$ or $3(5 / 33,15 \%)$ d. On d 0 and 7 and the day of AI, a vaginoscopy was performed and VD scored on a 4 -point scale $(0=$ clear mucus, $1=$ mucus containing flecks of pus, $2=$ discharge containing less than $50 \%$ pus, and $3=$ discharge containing more than $50 \%$ pus) according to Sheldon et al. (2006). A discharge sample for bacteriological examination was taken near the cervical os through the speculum using a sterile cotton swab. Additionally, a cytological and bacteriological sample was obtained from the endometrium immediately before insemination with a cytobrush as previously described (Kasimanickam et al., 2005). In brief, the cytobrush (Gynobrush; Heinz Herenz Medizinalbedarf GmbH, Hamburg, Germany) was protected by a disposable catheter and a sterile plastic sheet to avoid contamination. After cleaning the vulva with dry cellulose wipes, the instrument was inserted via the cervix into the uterine cavity guide manually by transrectal palpation. Inside the uterus, the sleeve was retracted and the brush rolled along the uterine endometrium. Still in the uterus, the brush was retracted into the catheter to avoid contamination during the passage through the anterior genital tract. The brush was immediately rolled onto a sterile microscope slide, fixed (LT-SYS; Labor und Technik, Berlin, Germany), and subsequently stored in a transport medium (Uni-Ter Amies CLR; Meus s.r.l., Piove di Sacco, Italy) for bacteriological analysis. Three hundred cells were counted under a microscope $(400 \times$ magnification) to determine the proportion of polymorphonuclear neutrophils (PMN). Cows with more than 10\% PMN were considered positive for an inflammatory process in the uterus (Kasimanickam et al., 2004).

Bacteriological samples were cultured for aerobic bacteria by common methods for bacteriological testing (Bisping and Amtsberg, 1988; Rolle and Mayr, 2006). Briefly, material from the brush was streaked onto sheep blood agar plates with a sterile disposable plastic eye. Plates were incubated for $48 \mathrm{~h}$ in aerobic conditions before bacterial speciation. Bacteria were identified on the basis of the characteristics of the colony, Gram stain, morphology, hemolysis, biochemical profile, and other standard tests. Plates containing 1 or more colony-forming units were considered a positive bacterial growth. The growth for potential uterine pathogens such as A. pyogenes, coliforms, and Streptococcus spp. (Huszenicza et al., 1999) was classified $(0=$ no growth, $1=1$ to 4 colonies, $2=5$ to 10 colonies, $3=11$ to 20 colonies, and $4=$ more than 20 colonies).

Data were downloaded into an Excel spreadsheet (Office 2010; Microsoft Corp., Redmond, WA) and statistical analyses were performed with SPSS for Windows (version 19.0; SPSS Inc., Munich, Germany). Bacterial contamination of the vagina and uterus, as well as the class of vaginal discharge score were compared between the 2 treatments by chi-square analysis. The level of significance was $\alpha=0.05$ and the confidence interval was $95 \%$.

Nine of 21 heifers in the group tail lost the P4 insert before d 7 and were excluded. All heifers from group tail developed a vaginal discharge classified as VD score (VDS) 2 or 3 (Table 1). Significantly more heifers had lower VDS in the no tail group compared with the tail group $(P<0.05)$. In all heifers with $\operatorname{VDS} 3(\mathrm{n}=9), A$. pyogenes was isolated.

The vaginal discharge improved in all heifers up to the day of AI. Only 2 heifers had VDS 2 on the day of AI. On the day of AI, distribution of VDS between the tail group and the no tail group was similar $(P=$ $0.73)$. We assume that removal of the irritating insert in combination with prostaglandin increased mucus production, which may have supported bacterial clearance from the reproductive tract.

Coliforms and Streptococcus spp. were isolated from the vagina of $6 / 33(18 \%)$ and $15 / 33(45 \%)$ heifers, respectively, on d 0 (Table 2). Arcanobacterium pyogenes 
Table 1. Numbers (and percentages in parentheses) of cows with different vaginal discharge scores on $\mathrm{d} 7$ and day of AI, considering the tail group with complete progesterone insert and the no tail group with the tail of the insert removed

\begin{tabular}{|c|c|c|c|c|c|c|c|c|}
\hline \multirow[b]{3}{*}{ Group } & \multicolumn{8}{|c|}{ Vaginal discharge score at } \\
\hline & \multicolumn{4}{|c|}{ d 7} & \multicolumn{4}{|c|}{ Day of AI } \\
\hline & 0 & 1 & 2 & 3 & 0 & 1 & 2 & 3 \\
\hline Tail $(\mathrm{n}=12)$ & 0 & 0 & $6(50)$ & $6(50)$ & $6(50)$ & $6(50)$ & 0 & 0 \\
\hline No tail $(\mathrm{n}=21)$ & 0 & $6(29)$ & $12(57)$ & $3(14)$ & $7(33)$ & $12(57)$ & $2(10)$ & 0 \\
\hline All $(\mathrm{n}=33)$ & 0 & $6(18)^{*}$ & $18(55)^{*}$ & $9(27)$ & $13(35)$ & $18(55)$ & $2(10)$ & 0 \\
\hline
\end{tabular}

was not found in any of these swabs. On the day of removal of the $\mathrm{P} 4$ insert (d 7), all but 1 vaginal swab were positive for 1 or more types of pathogens. Significantly more vaginal samples of the tail group were infected with Escherichia coli compared with the no tail group $(P<0.05)$. On the day of AI, $5(15 \%), 10(30 \%)$, and $7(21 \%)$ of 33 vaginal swabs were positive for A. pyogenes, coliforms, and Streptococcus spp., respectively. From the uterus, A. pyogenes, coliforms and Streptococcus spp. could be isolated in 4 (12\%), 16 (48\%), and 4 $(12 \%)$ of the 33 cytobrushes, respectively, on the day of AI. The frequency distribution did not differ between the 2 treatments.

On the day of AI, PMN were found in 11 out of 33 heifers (Table 3). Seven of $33(21 \%)$ heifers exceeded the threshold of 5\% PMN for which Gilbert et al. (2005) found a negative influence on subsequent fertility. Two heifers exceeded the threshold of $10 \%$ PMN, indicative of endometritis in cows $40 \mathrm{~d}$ postpartum, following the definition of Kasimanickam et al. (2004). There was no effect of the presence or absence of the tail.

In this study, P4 inserts were lost significantly more frequently in the tail group (0 vs. $7 ; P<0.05)$. We speculate that the blue tail is attractive for curious herd mates that might pull out the insert by licking the protruding tail. Although several trials have been performed with the same type of $\mathrm{P} 4$ insert used in our study, only few describe systematic monitoring for losses. von Krueger and Heuwieser (2011) reported the loss of 7 out of 16 inserts at the beginning of their study.

Purulent vaginal discharge as a sign of endometritis is known to be associated with reduced conception rates in cows (LeBlanc et al., 2002; Sheldon et al., 2002; Williams et al., 2005). Progesterone inserts improve conception rates in heifers (Lucy et al., 2001) and are efficacious to synchronize estrus in cows (Rivera et al., 2005). Prevalence of cloudy to yellow vaginal discharge, however, was substantial in 2 studies with large sample sizes: 50\% ( $\mathrm{n}=249$; Walsh et al., 2007) and 67\% (n $=863$; Chenault et al., 2003). In the present study, all heifers developed purulent discharge at $\mathrm{d} 7$, when P4 inserts were removed. Bacteriological investigation revealed common pyogenic bacteria in the vaginal swabs. Arcanobacterium pyogenes, coliforms, and Streptococcus spp. were found in 32 of 33 heifers. These data demonstrate bacterial contamination following 7-d treatment with a $\mathrm{P} 4$ insert. In all severe cases (VDS 3, $\mathrm{n}=9$ ), A. pyogenes could be isolated from the vagina. These results are in agreement with an earlier study (Padula and Macmillan, 2006) that demonstrated a heavy growth of bacteria on vaginal swabs in 61 early postpartum beef cows after 7 -d treatment with $\mathrm{P} 4$ or

Table 2. Bacteriological results considering sampling location and the 2 groups (tail and no tail)

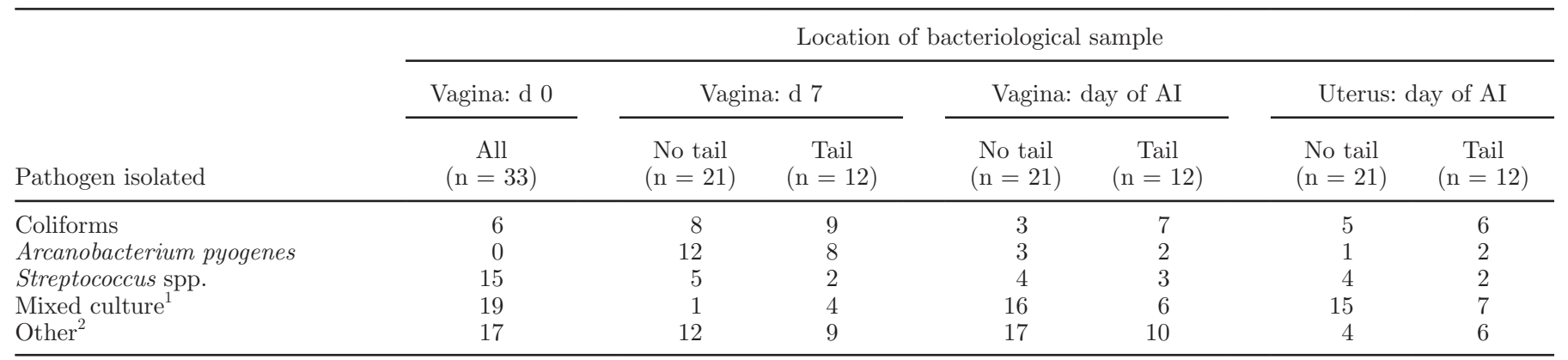

${ }^{1}$ Coliforms, Sarcina spp., and CNS.

${ }^{2}$ Corynebacterium bovis, CNS, Pseudomonas spp., and Sarcina spp. 
Table 3. Percent polymorphonuclear neutrophils in the endometrium on the day of AI, considering the 2 groups (tail and no tail)

\begin{tabular}{lrccc}
\hline & \multicolumn{4}{c}{$\begin{array}{c}\text { Polymorphonuclear } \\
\text { neutrophils }\end{array}$} \\
\cline { 2 - 5 } Group & 0 & $<5$ & $>5$ & $>10$ \\
\hline Tail $(\mathrm{n}=12)$ & 8 & 1 & 2 & 1 \\
No tail $(\mathrm{n}=21)$ & 14 & 3 & 3 & 1 \\
All $(\mathrm{n}=33)$ & 22 & 4 & 5 & 2 \\
\hline
\end{tabular}

hormone-free inserts. Bulman et al. (1978) isolated only ubiquitary bacteria in 9 out of 10 dairy cows after 7 and 14-d treatment.

At the time of insemination, the VDS had improved considerably. Except for 2 heifers, clear (VDS 0) to clear mucus with flecks of pus (VDS 1) was diagnosed. Bacteriological findings, however, showed evidence of pyogenic bacteria in the vagina. A similar bacteriological flora could be isolated from the endometrium in 30 heifers. So far, data are not available describing the bacteriological flora in the uterus at the day of AI after the treatment of $\mathrm{P} 4$ inserts. We enrolled only virgin heifers that had not been previously inseminated; thus, we assume that the uterine cavity was sterile at the beginning of $\mathrm{P} 4$ supplementation. Also, we were cautious to avoid contamination of the swab in the vagina as much as possible by using a speculum and a doublesheeted brush. This method has been used repeatedly to collect bacteriological samples from the uterine cavity (Sheldon et al., 2002). Data on contamination of the uterus using this technique are not available. Our bacteriological findings have relevance, as it has been shown that $A$. pyogenes in the uterus of cows up to $5 \mathrm{wk}$ after calving decreased the conception rate significantly from 64 to $26 \%$ (Huszenicza et al., 1999).

Cytological results of the endometrium did not provide evidence of endometritis in P4-treated heifers. In only 2 heifers, the proportion of PMN exceeded the threshold of $10 \%$, indicative of an inflammatory process in the uterus. It was discussed that vaginal P4 inserts cause mechanical irritations and, thus, discharge (Ahmadi et al., 2007). The protruding tail has been blamed for ascending infections or enhancing mechanical irritations (Walsh et al., 2008). On d 7, VDS in the tail group were significantly higher than in the no tail group (Table $2 ; P<0.05$ ). We speculate that the protruding tail allows bacteria to ascend into the genital tract or enhances mechanical irritations of the vagina. At the day of AI, the VDS in both treatments was similar.

The results of this study confirm that treatment with $\mathrm{P} 4$ inserts can cause purulent vaginitis. Pyogenic bacteria were found in the uterus after treatment with $\mathrm{P} 4$ inserts. Furthermore, the protruding tail is associated with insert losses and had an influence on the severity of the vaginal discharge up to d 7. Nevertheless, previous studies have shown that the vaginal discharge does not negatively influence the efficacy of P4 inserts.

von Krueger and Heuwieser (2011) reported that $91.9 \%$ of P4-treated heifers had VDS of 2 or 3, indicative of vaginal irritation. However, these did not affect the pregnancy outcome in P4-treated heifers (odds ratio $=0.652,95 \% \mathrm{CI}=0.235-1.810 ; P=0.411)$. More heifers were pregnant in the $\mathrm{P} 4$ group than in an untreated control group due to a higher service rate (91.4 vs. 70.4\%; von Krueger and Heuwieser, 2011). Further research should elucidate whether the bacterial contamination of the genital tract have an effect on fertility.

\section{REFERENCES}

Ahmadi, M. R., S. Nazifi, J. Sajedianfard, and G. Moattari. 2007. Impact of estrous synchronization methods on cellular proportions in cervical mucus and serum hormone concentrations. Theriogenology 67:598-604.

Bisping, W., and G. Amtsberg. 1988. Pages 15-38 (chapters 1 and 2) in Colour Atlas for the Diagnosis of Bacterial Pathogens in Animals. Paul Parey Scientific Publishers, Berlin and Hamburg, Germany.

Bulman, D. C., P. E. McKibbin, W. T. Appleyard, and G. E. Lamming. 1978. Effect of a progesterone-releasing intravaginal device on the milk progesterone levels, vaginal flora, milk yield and fertility of cyclic and non-cyclic dairy cows. J. Reprod. Fertil. 53:289-296.

Chebel, R. C., J. E. Santos, R. L. Cerri, H. M. Rutigliano, and R. G. Bruno. 2006. Reproduction in dairy cows following progesterone insert presynchronization and resynchronization protocols. J. Dairy Sci. 89:4205-4219.

Chenault, J. R., J. F. Boucher, K. J. Dame, J. A. Meyer, and S. L. Wood-Follis. 2003. Intravaginal progesterone insert to synchronize return to estrus of previously inseminated dairy cows. J. Dairy Sci. 86:2039-2049.

Dubuc, J., T. F. Duffield, K. E. Leslie, J. S. Walton, and S. J. LeBlanc. 2010. Definitions and diagnosis of postpartum endometritis in dairy cows. J. Dairy Sci. 93:5225-5233.

Gilbert, R. O., S. T. Shin, C. L. Guard, H. N. Erb, and M. Frajblat. 2005. Prevalence of endometritis and its effects on reproductive performance of dairy cows. Theriogenology 64:1879-1888.

Huszenicza, G., M. Fodor, M. Gacs, M. Kulcsar, M. J. W. Dohmen, M. Vamos, L. Porkolab, T. Kegl, J. Bartyik, J. A. C. M. Lohuis, S. Janosi, and G. Szita. 1999. Uterine bacteriology, resumption of cyclic ovarian activity and fertility in postpartum cows kept in large-scale dairy herds. Reprod. Domest. Anim. 34:237-245.

Kasimanickam, R., T. F. Duffield, R. A. Foster, C. J. Gartley, K. E. Leslie, J. S. Walton, and W. H. Johnson. 2004. Endometrial cytology and ultrasonography for the detection of subclinical endometritis in postpartum dairy cows. Theriogenology 62:9-23.

Kasimanickam, R., T. F. Duffield, R. A. Foster, C. J. Gartley, K. E. Leslie, J. S. Walton, and W. H. Johnson. 2005. A comparison of the cytobrush and uterine lavage techniques to evaluate endometrial cytology in clinically normal postpartum dairy cows. Can. Vet. J. 46:255-259.

Lamb, G. C., J. S. Stevenson, D. J. Kesler, H. A. Garverick, D. R. Brown, and B. E. Salfen. 2001. Inclusion of an intravaginal progesterone insert plus $\mathrm{GnRH}$ and prostaglandin $\mathrm{F}_{2 \alpha}$ for ovulation control in postpartum suckled beef cows. J. Anim. Sci. 79:2253-2259.

LeBlanc, S. J., T. F. Duffield, K. E. Leslie, K. G. Bateman, G. P. Keefe, J. S. Walton, and W. H. Johnson. 2002. Defining and diag- 
nosing postpartum clinical endometritis and its impact on reproductive performance in dairy cows. J. Dairy Sci. 85:2223-2236.

Lucy, M. C., H. J. Billings, W. R. Butler, L. R. Ehnis, M. J. Fields, D. J. Kesler, J. E. Kinder, R. C. Mattos, R. E. Short, W. W. Thatcher, R. P. Wettemann, J. V. Yelich, and H. D. Hafs. 2001. Efficacy of an intravaginal progesterone insert and an injection of $\mathrm{PGF}_{2 \alpha}$ for synchronizing estrus and shortening the interval to pregnancy in postpartum beef cows, peripubertal beef heifers, and dairy heifers. J. Anim. Sci. 79:982-995.

Padula, A. M., and K. L. Macmillan. 2006. Effect of treatment with two intravaginal inserts on the uterine and vaginal microflora of early postpartum beef cows. Aust. Vet. J. 84:204-208.

Rivera, H., H. Lopez, and P. M. Fricke. 2005. Use of intravaginal progesterone-releasing inserts in a synchronization protocol before timed AI and for synchronizing return to estrus in Holstein heifers. J. Dairy Sci. 88:957-968.

Rolle, M., and A. Mayr. 2006. Medizinische Mikrobiologie, Infektionsund Seuchenlehre. 8th rev. ed. Enke Verlag, Stuttgart, Germany.

Sheldon, I. M., G. S. Lewis, S. LeBlanc, and R. O. Gilbert. 2006. Defining postpartum uterine disease in cattle. Theriogenology 65:1516-1530.

Sheldon, I. M., D. E. Noakes, A. N. Rycroft, D. U. Pfeiffer, and H. Dobson. 2002. Influence of uterine bacterial contamination after parturition on ovarian dominant follicle selection and follicle growth and function in cattle. Reproduction 123:837-845.
Stevenson, J. L., J. A. Rodrigues, F. A. Braga, S. Bitente, J. C. Dalton, J. E. Santos, and R. C. Chebel. 2008. Effect of breeding protocols and reproductive tract score on reproductive performance of dairy heifers and economic outcome of breeding programs. J. Dairy Sci. 91:3424-3438.

Stevenson, J. S., J. R. Pursley, H. A. Garverick, P. M. Fricke, D. J. Kesler, J. S. Ottobre, and M. C. Wiltbank. 2006. Treatment of cycling and noncycling lactating dairy cows with progesterone during Ovsynch. J. Dairy Sci. 89:2567-2578.

von Krueger, X., and W. Heuwieser. 2011. Effect of CIDR ${ }^{\circledR}$ on 4-dayservice-rate, pregnancy rate and vaginal irritation in dairy heifers. Tierarztl. Prax. Ausg. Grosstiere Nutztiere 39:277-280.

Walsh, R. B., S. J. LeBlanc, T. D. Duffield, D. F. Kelton, J. S. Walton, and K. E. Leslie. 2007. Synchronization of estrus and pregnancy risk in anestrous dairy cows after treatment with a progesteronereleasing intravaginal device. J. Dairy Sci. 90:1139-1148.

Walsh, R. B., S. J. LeBlanc, E. Vernooy, and K. E. Leslie. 2008. Safety of a progesterone-releasing intravaginal device as assessed from vaginal mucosal integrity and indicators of systemic inflammation in postpartum dairy cows. Can. J. Vet. Res. 72:43-49.

Williams, E. J., D. P. Fischer, D. U. Pfeiffer, G. C. England, D. E. Noakes, H. Dobson, and I. M. Sheldon. 2005. Clinical evaluation of postpartum vaginal mucus reflects uterine bacterial infection and the immune response in cattle. Theriogenology 63:102-117. 